\title{
Metallothionein Messenger RNA Regulation in the Mottled Mouse and Menkes Kinky Hair Syndrome
}

\author{
Seymour Packman, * Richard D. Palmiter," Michael Karin," and Cynthia O'Toole* \\ ${ }^{*}$ Division of Genetics, Department of Pediatrics, University of California, San Francisco, San Francisco, California $94143 ;{ }^{\ddagger}$ Howard \\ Hughes Medical Institute Laboratory, Department of Biochemistry, University of Washington, Seattle, Washington 98195; and \\ ${ }^{\S}$ Division of Pharmacology, University of California, San Diego, La Jolla, California 92093
}

\begin{abstract}
Menkes kinky hair syndrome is an X-linked neurodegenerative disorder, causing tissue-specific increases in copper and metallothionein content. A mouse model is provided by hemizygotes for mutant alleles at the $\mathrm{X}$-linked mottled locus. Herein we test the possibility that the primary defect in both species is in metallothionein gene regulation.

We show that metallothionein-I messenger RNA (mRNA) (mouse) and metallothionein-II mRNA (human) are elevated in mutant fibroblasts. However, comparable dose-response curves in mutant and control cells are generated when mouse metallothionein-I mRNA concentrations are measured in cells exposed to varying concentrations of cadmium or copper (metallothionein inducers). Furthermore, when mutant and control cells are grown to achieve overlapping intracellular copper concentrations in the two cell types, metallothionein-I (mouse) and metallothioneinII (human) mRNA levels are proportional to the intracellular copper concentrations. Finally, in paired determinations in blotchy hemizygote and littermate kidneys containing comparable copper levels, metallothionein-I mRNA contents are very similar.

The observations suggest that elevated intracellular copper in these mutants induces metallothionein synthesis by normal regulatory mechanisms.
\end{abstract}

\section{Introduction}

Menkes kinky hair syndrome is an X-linked recessive disorder with decreased serum copper and ceruloplasmin-copper oxidase, and tissue-specific increases in copper content. Patients manifest pili torti, hypopigmentation, hypothermia, growth failure, skeletal defects, arterial aneurysms, seizures, and progressive degeneration of the central nervous system, with death by age $3 \mathrm{yr}$. Prominent postmortem findings include gliosis, neuronal degeneration, and defects of the arterial intima (1).

Mice hemizygous for mutant alleles at the X-linked mottled locus $(2,3)$ provide an animal model of Menkes kinky hair syndrome. Striking correspondences in distinctive clinical, pathologic, and chemical features (2-8) suggest that the human and

Portions of this work were presented to the annual meetings of the American Society of Human Genetics (1982 and 1985), and published in abstract form: Am. J. Hum. Genet. 1982. 34:59A and 1985. 37:A14.

Address correspondence to Dr. Packman, Division of Genetics, Department of Pediatrics, University of California, San Francisco, San Francisco, CA 94143.

Received for publication 15 October 1986.

J. Clin. Invest.

(c) The American Society for Clinical Investigation, Inc.

0021-9738/87/05/1338/05 \$1.00

Volume 79, May 1987, 1338-1342 murine X-linked recessive diseases represent defects at a locus serving the same function in both species. The $X$ linkage itself is strongly supportive of identity, since X-linked loci are highly conserved through evolution (9).

The basic defect is unknown. The recent assignment of mouse $(10)$ and human $(11,12)$ metallothionein genes to autosomes argues strongly against a primary structural defect in that class of proteins. However, hypotheses of defective modulation of metallothionein function, abnormal transport of metals, or aberrent quantitative regulation of metallothioneins remain to be considered.

In the present work, we ask whether the regulation of metallothionein mRNA synthesis is abnormal in the mottled and kinky hair syndrome mutants. Toward this end, we note comparable metallothionein mRNA concentrations in control and mutant mouse cells in response to metallothionein inducers, we document indistinguishable metallothionein levels in mutant (mouse and human) and control fibroblasts containing equivalent intracellular copper concentrations, and we find no elevations in metallothionein messenger RNA (mRNA) concentrations in a mutant mouse tissue at early developmental stages, before sequestration of excessive copper.

The results support the suggestion (13) that metallothionein mRNA accumulation in mutant cells is a secondary consequence of an independent and specific alteration in copper transport or in delivery to a copper transport system. This interpretation differs in emphasis from inferences drawn in recent studies of metallothionein and metallothionein mRNA synthesis in Menkes syndrome (14).

\section{Methods}

Mutants. Murine cultured skin fibroblasts were derived from mice hemizygous for the blotchy mutant allele at the mottled locus $\left(\mathrm{Mo}^{\mathrm{blo}} / \mathrm{y}\right)$, and from normal male littermates $(+/ y)$. All experiments that compared mutants (blotchy) and controls were performed in cells derived from littermate pairs. Mutant and control mice were obtained as offspring of heterozygous females $\left(\mathrm{Mo}^{\mathrm{blo}} /+\right.$ ) and normal males, both of strain C57BL/ $6 \mathrm{~J}$, and purchased as breeding pairs from Jackson Memorial Laboratory, (Bar Harbor, ME). We have previously shown (8) that blotchy cultured skin fibroblasts so established express the mutant phenotype of excessive copper sequestration and reduced efflux (15), independent of passage number. Cells of passage numbers 10-15 were used in experiments.

Menkes kinky hair syndrome fibroblasts were obtained from the National Institute of General Medical Sciences, Human Genetic Mutant Cell Repository (Camden, NJ), as cultures numbered GM 0220, 1057, and 1981. Age-matched control male fibroblast cultures were either obtained from the Repository (GM 498 and 970) or established from patients or their relatives treated for conditions entirely unrelated to trace metal metabolism at the University of California, San Francisco. Cells at passage numbers 5-10 were used in experiments.

Cell propagation. Fibroblast cultures were propagated in plastic $\mathrm{T}$ flasks at $8 \% \mathrm{CO}_{2}, 37^{\circ} \mathrm{C}$, in Dulbecco's modified Eagle's $\mathrm{H} 21$ medium, 
with fetal calf serum to $10 \%(\mathrm{vol} / \mathrm{vol})$ and added penicillin and streptomycin $(100 \mathrm{U} / 10 \mathrm{ml}$ and $100 \mu \mathrm{g} / 10 \mathrm{ml}$, respectively) in the complete medium. To propagate cells for experiments, confluent cultures were harvested with $0.15 \%$ Pronase, rinsed and pelleted in Hanks'-CMF $\left(\mathrm{Ca}^{++}\right.$ and $\mathrm{Mg}^{++}$free) solution, resuspended in complete medium, plated onto tissue culture dishes as a 1:2 (mouse) or 1:3 (human) split, and regrown to confluent density for experimental studies as noted in the text. The copper concentration in baseline complete medium is $0.76 \mu \mathrm{M}$, as determined by atomic absorption spectrophotometry (cf. below).

Copper determinations. Copper concentrations were determined in whole cell extracts and in mouse organs by atomic absorption spectrophotometry (13) using an atomic absorption spectrophotometer (model 2380; Perkin-Elmer Corp., Norwalk, CT) with an HGA 400 graphite furnace. Concentrations in fibroblasts are expressed per milligram of protein, with protein determinations performed by a modified Lowry procedure (16). Concentrations in organ samples are expressed per wet weight (milligram) of tissue. Copper concentrations in extracts were such as to provide samples for analysis containing absolute copper contents that were 100-15,000 times the graphite furnace detection limits.

Nucleic acid analysis. Total nucleic acids were isolated from whole cell extracts and mouse organs by proteinase $\mathrm{K}$-sodium dodecyl sulfate digestion, followed by phenol-chloroform extraction, as described (17). Mouse metallothionein-I mRNA levels were measured by solution hybridization using a cloned mouse metallothionein-I ${ }^{32} \mathrm{P}$-labeled complementary DNA (cDNA) probe, as reported (17-19). Human metallothionein-II mRNA concentrations were measured according to published procedures (12) by densitometric analysis of Northern blots after hybridization with a human metallothionein-II cDNA probe (20), as well as with human metallothionein-IIA (21) and metallothionein-IA (22) gene-specific probes. Densitometric quantitation was performed with a soft laser densitometer (Zeineh, supplied by Biomed Instruments Inc., Fullerton, CA), with film exposures within the linear range of the densitometer.

\section{Results}

We first asked whether the cellular phenotype of the mottled and kinky hair syndrome mutations, namely, copper sequestration and metallothionein accumulation (15), is reflected in the content of metallothionein-I mRNA. Accordingly, blotchy and control cells were grown to confluence in base line complete medium, and mouse metallothionein-I mRNA concentrations were measured in these cells by solution hybridization to a cloned mouse metallothionein cDNA probe (17). Under these basal conditions, metallothionein-I mRNA concentration in normal cells was $0.51 \pm 0.11(8) \mathrm{pg} \mathrm{mRNA} / \mu \mathrm{g}$ total nucleic acid (mean \pm SEM [number of independent determinations]), while the concentration in blotchy cells was $2.51 \pm 0.63(9) \mathrm{pg}$ mRNA/ $\mu \mathrm{g}$ total nucleic acid. The fivefold elevation in blotchy cells was significant $(P<0.01)$ when analyzed according to Wilcoxon's two-sample rank test (23).

In addressing the possibility that such elevated metallothionein mRNA levels represent a primary aberration, we first asked whether there were differential changes in metallothionein mRNA levels in response to growth of cells in cadmium, a metallothionein inducer. In fact, with exposure of cells to increasing concentrations of cadmium (up to $5 \mu \mathrm{M}$ ), dose-response curves in controls and blotchy were similar (Fig. 1). Beyond $5 \mu \mathrm{M}$ cadmium, maximal metallothionein-I mRNA levels were slightly higher in blotchy (Fig. 1).

Comparable dose-response curves in blotchy and controls were also observed with cells exposed to increasing concentrations of copper (Fig. 2). The patterns of response were similar in the two cell types, whereas after cell growth at any given

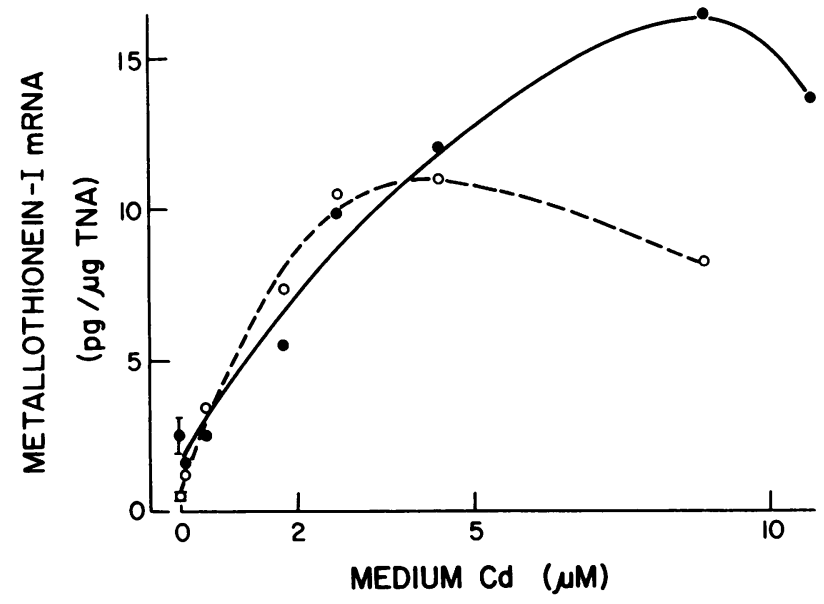

Figure 1. Effect of cadmium concentration on metallothionein-I mRNA content. Control ( 0 ) and mutant (blotchy) (๑) fibroblasts were derived, propagated, and prepared for experiment as in Methods. After exposure for $18 \mathrm{~h}$ to concentrations of cadmium (as $\mathrm{CdSO}_{4}$ ) as indicated (abscissa), cells were harvested and metallothionein-I mRNA concentrations determined (ordinate) as in Methods. MetallothioneinI mRNA concentrations are in picograms mRNA per microgram total nucleic acid (TNA).

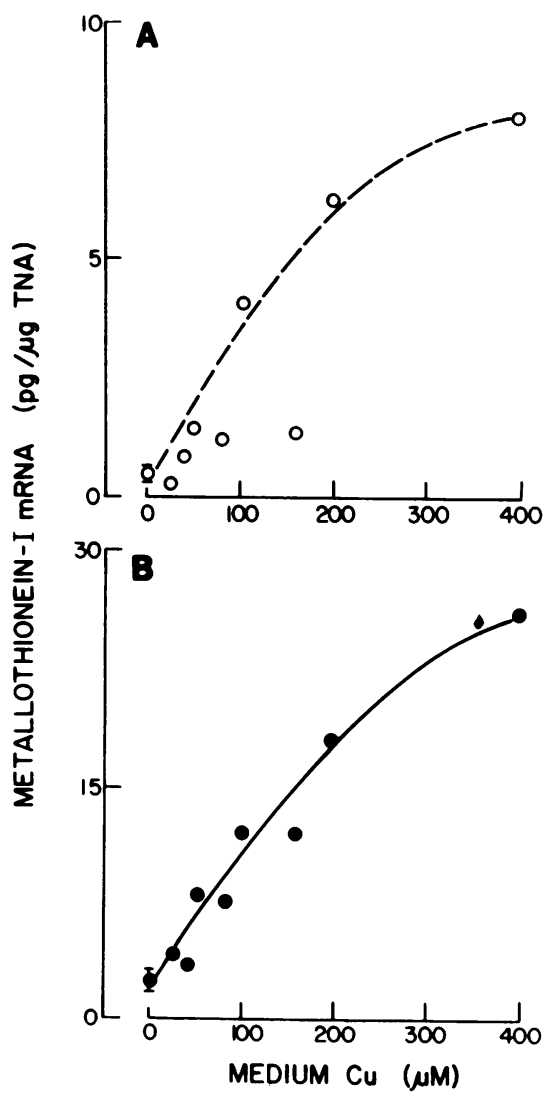

Figure 2. Effect of copper concentration on metallothionein-I mRNA content. Control $(A)(0)$ and mutant (blotchy) $(B)(\bullet)$ fibroblasts were derived, propagated, and prepared for experiments as in Methods. After exposure for $18 \mathrm{~h}$ to concentrations of copper (as $\mathrm{CuCl}_{2}$ ) as indicated (abscissa), cells were harvested and metallothionein-I mRNA concentrations determined (ordinate) as in Methods. MetallothioneinI mRNA concentrations are expressed as in Fig. 1. 
copper concentration in the medium, actual metallothionein-I mRNA levels were threefold higher in blotchy.

While aberrant quantitative regulation of metallothionein by copper was not entirely ruled out by the above result, we postulated that the higher metallothionein-I mRNA concentration in mutant cells might represent a secondary phenomenon, attributable to corresponding differences in intracellular copper concentrations. Accordingly, mutant and control cells with equivalent intracellular copper levels would also contain comparable metallothionein mRNA levels.

To test this prediction, blotchy and control cells were grown in a range of copper in the medium so as to effect overlapping intracellular copper concentrations in the two cell types (13). Over a range of intracellular copper up to $0.18 \mu \mathrm{g}$ copper $/ \mathrm{mg}$ cell protein, intracellular metallothionein-I mRNA levels were proportional to intracellular copper concentrations (Fig. 3). When subject to a two-tailed test using the Student's $t$ statistic (24), the slopes of the regression lines-drawn for metallothionein-I mRNA levels as a function of intracellular copper content-reveal the control and mutant data points as indistinguishable $(P>0.10)$.

When similar experiments were performed in a series of kinky hair syndrome fibroblasts and controls, the data were entirely supportive of the results obtained in the mouse mutants. Menkes syndrome fibroblasts contained elevated basal levels of metallothionein-II mRNA (Table I). Fourfold higher extracellular copper concentrations were required to achieve a level of metallothionein-II mRNA in control cells similar to that in Menkes cells. Finally, considering each experiment independently, when control cell intracellular copper concentrations were raised sufficiently to overlap mutant levels, metallothionein-II

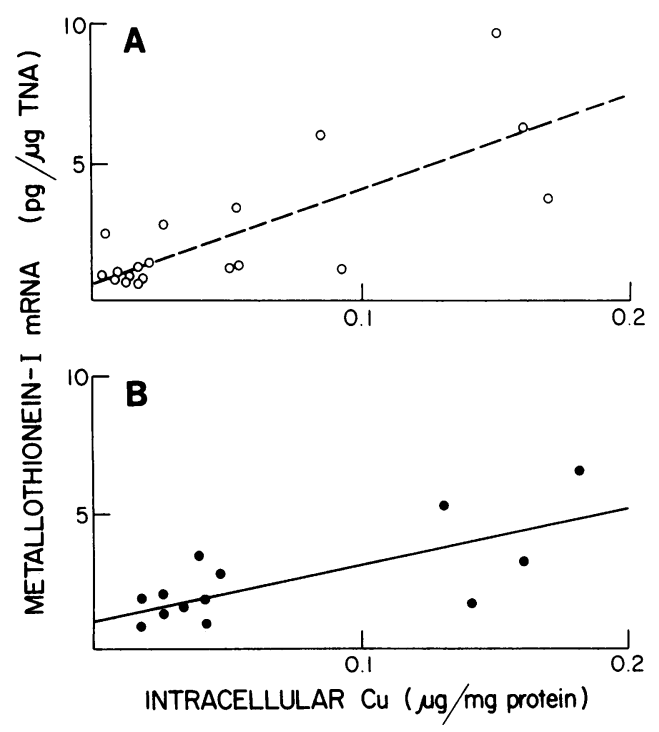

Figure 3. Mutant and control metallothionein-I mRNA contents at comparable intracellular copper concentrations. Blotchy $(B)(\bullet)$ and control $(A)(0)$ fibroblasts were derived, propagated, and prepared for experiment as in Methods. Duplicate cultures were exposed for $18 \mathrm{~h}$ to medium copper (as $\left.\mathrm{CuCl}_{2}\right)$ concentrations $(0-200 \mu \mathrm{M} \mathrm{Cu}$ for controls, 0-50 $\mu \mathrm{M} \mathrm{Cu}$ for blotchy) previously shown (13) to effect overlapping intracellular copper concentrations. After such exposure to copper, cells were harvested, and intracellular copper and metallothionein-I mRNA concentrations were determined, each in one of the duplicate cultures, as described in Methods. Metallothionein-I mRNA concentrations are expressed as in Fig. 1.
Table I. Metallothionein-II mRNA Levels in Human Fibroblasts

\begin{tabular}{|c|c|c|c|c|c|}
\hline & \multirow{2}{*}{$\begin{array}{l}\text { Medium } \\
\mathrm{Cu}^{*}\end{array}$} & \multicolumn{2}{|l|}{ Cell $\mathrm{Cu}$} & \multicolumn{2}{|c|}{$\begin{array}{l}\text { Relative MT-II } \\
\text { mRNA levels }^{*}\end{array}$} \\
\hline & & Control & Menkes & Control & Menkes \\
\hline & $\mu m$ & $\begin{array}{l}\mu \mathrm{g} / \mathrm{mg} \\
\text { protein }\end{array}$ & $\begin{array}{l}\mu g / m g \\
\text { protein }\end{array}$ & & \\
\hline \multirow[t]{5}{*}{ Experiment $1^{\S}$} & 0 & 0.045 & 0.22 & 1.0 & 3.0 \\
\hline & 25 & - & 0.23 & - & 4.0 \\
\hline & 100 & 0.083 & 0.25 & 2.0 & 6.0 \\
\hline & 200 & 0.14 & - & 3.0 & - \\
\hline & 400 & 0.29 & - & 10.0 & - \\
\hline \multirow[t]{5}{*}{ Experiment 2} & 0 & 0.025 & 0.074 & 1.0 & 2.8 \\
\hline & 25 & - & 0.074 & - & 5.0 \\
\hline & 100 & - & 0.15 & - & 12.0 \\
\hline & 200 & 0.062 & - & 2.6 & - \\
\hline & 400 & 0.22 & - & 12.0 & - \\
\hline \multirow[t]{5}{*}{ Experiment 3} & 0 & 0.035 & 0.066 & 1.0 & 2.4 \\
\hline & 25 & - & 0.081 & - & 4.4 \\
\hline & 100 & 0.043 & 0.11 & 2.1 & 7.4 \\
\hline & 200 & 0.073 & - & 2.4 & - \\
\hline & 400 & 0.18 & - & 8.6 & - \\
\hline
\end{tabular}

* Exposure was for $18 \mathrm{~h}$ to $\mathrm{Cu}$ as added $\mathrm{CuCl}_{2}$, as described in Methods and in legend to Fig. 3.

${ }^{\ddagger}$ Metallothionein-II (MT-II) quantitation by densitometric analysis of Northern blots after hybridization with a human MT-II cDNA probe, as in Methods. Levels are all relative to control cells grown in $0 \mu \mathrm{M}$ $\mathrm{Cu}$.

${ }^{8}$ Independent, paired experiments are arbitrarily numbered 1-3.

mRNA concentrations in control cells increased to levels comparable to that in mutant cells (Table I). Virtually identical results were obtained with a metallothionein-IIA cDNA probe (Table I), and with metallothionein-IA and -IIA gene-specific probes (data not shown).

Finally, the mottled mouse system permitted us to ask whether metallothionein-I mRNA levels were concordant with mutant tissue copper concentrations. Mutant tissues such as kidney express the phenotype of copper sequestration (7), but may not yet have accumulated elevated copper contents in very young hemizygotes ( $\leq 10 \mathrm{~g}$ body $\mathrm{wt}$ ). In four independent determinations, intracellular copper and metallothionein-I mRNA concentrations were measured in such early paired blotchy and littermate kidneys. The range of mRNA concentrations was quite similar in blotchy and controls (Table II), even in the face of slightly higher tissue copper contents in these young mutant kidneys.

\section{Discussion}

The basic defect in Menkes kinky hair syndrome and in the murine analogue for that disease, the mottled mouse, is unknown. It was determined early on that the phenotype in both species was potentially attributable to defective gastrointestinal absorption of copper, relative copper deficiency, and consequent reduced activity of a number of cuproenzymes (1-3, 15, 25). The defective gastrointestinal absorption was only one mani- 
Table II. Copper and Metallothionein-I mRNA Levels in Mouse Kidney

\begin{tabular}{lll}
\hline & Copper* & MT-I mRNA \\
\hline Hemizygote & 3.3 & 0.53 \\
Control & 2.3 & 0.48 \\
Hemizygote & 1.6 & 0.35 \\
Control & 1.1 & 0.39 \\
Hemizygote & 3.0 & 0.70 \\
Control & 1.1 & 0.67 \\
Hemizygote & 3.0 & 0.39 \\
Control & 1.8 & 0.40
\end{tabular}

* Copper concentrations as $10^{-3}$ micrograms copper per milligram tissue (wet weight).

${ }^{\ddagger}$ Metallothionein-I mRNA levels as picograms per microgram total nucleic acid.

${ }^{\S}$ Numbers refer to independent sets of determinations, each in littermate pairs.

festation of a tissue-specific copper sequestration and distribution defect (26); consequently, attention turned to mechanisms of intracellular copper binding.

Metallothioneins are relatively ubiquitous metalloproteins, identified as the major intracellular metal-binding protein in a variety of tissues (27). Increased concentrations of metallothioneins have repeatedly been demonstrated in mutant mouse and human cells and tissues $(15,27-31)$. However, studies done on mutants $(28,32)$ have shown a number of parameters of metallothionein function to be normal. Given the autosomal localization of mouse $(10)$ and human $(11,12)$ metallothionein genes, the mutation in X-linked Menkes syndrome or the mottled mouse almost certainly does not cause an alteration in the primary structure of metallothioneins. Accordingly, recent studies in the Menkes and the mottled mutants have been based on hypotheses of abnormal tissue-specific modulations of metallothionein function (7), primary defects in transport of copper $(13,28)$, or defective regulation of metallothionein synthesis (11, 14, 31).

In the present work, we addressed the possibility of an abnormality in metallothionein biosynthesis, in cultured skin fibroblasts of the mottled (blotchy) hemizygote, in fibroblasts from patients with Menkes syndrome, and in blotchy kidney. Each of these cell types is known to express the copper sequestration phenotype $(7,8,15)$.

Under baseline growth conditions, mouse metallothioneinI mRNA concentrations were significantly higher in blotchy than in control littermate fibroblasts. Similarly, kinky hair syndrome fibroblasts contained 2.5- to 3-fold higher basal levels of metallothionein-II mRNA as compared with normal fibroblasts. It is apparent that elevations of copper and metallothionein protein in mutant cells are reflected in elevations of metallothionein mRNA content.

Upon exposure to cadmium, a metallothionein inducer, metallothionein-I mRNA content increased in both blotchy and control cells. Very similar dose-response curves were obtained in the two cell types (Fig. 1), suggesting that the effects of cadmium on metallothionein synthesis may be identical in control and blotchy cells. This result is consistent with the conclusion drawn from indirect studies of metallothionein induction in Menkes cells (33).

A similarity of dose-response curves in blotchy and control cells was also observed with exposure of cells to copper (Fig. 2). However, the metallothionein-I mRNA content was appreciably higher in blotchy cells for a given concentration of copper in the medium. The medium copper concentration required to achieve a given metallothionein-I mRNA content in mutant cells was approximately one-fifth that which resulted in the same mRNA content in control fibroblasts. These results differed from those observed with cadmium, consonant with the suggestion $(8,28)$ that these mutations affect specifically cellular metabolism of copper, and not other trace metals.

Importantly, when blotchy and control cells were grown so as to achieve overlapping (elevated) intracellular copper concentrations in the two cell types, metallothionein-I mRNA levels were virtually the same at equivalent intracellular copper concentrations (Fig. 3). Similarly, metallothionein-II mRNA levels were quite comparable in Menkes and control fibroblasts at matching intracellular copper concentrations (Table I). These results in both Menkes and blotchy suggest that the elevations in metallothionein mRNA in mutant cells are highly correlated with an increased intracellular copper concentration, which must then have been caused by a distortion in cellular copper homeostasis independent of metallothionein regulation.

This contention is strengthened by the studies in blotchy kidney. Measurements were performed before elevations in kidney copper (i.e., when mutant and control kidneys showed comparable copper contents). In matched determinations in hemizygotes and littermates, kidney metallothionein-I mRNA contents were very similar (Table II). Therefore, the animal data support the notion that elevations in cellular copper precede secondary responses in metallothionein mRNA and metallothionein synthesis in these mutants.

Our data are consistent with those of a preliminary report in the mouse system (15) and recent studies in Menkes syndrome fibroblasts (14); however, our conclusions differ from one of the models put forth on the basis of the studies in Menkes fibroblasts (14). In that model, increased metallothionein and metallothionein mRNA synthesis were taken as indications of a primary abnormality in the regulation of metallothionein gene transcription. Addressing the major caveat identified by that model (14), namely, the effects of intracellular as opposed to extracellular copper, we argue that elevated metallothionein mRNA synthesis in these mutants is a secondary phenomenon, related to already increased intracellular copper levels. We note that the correlation of metallothionein mRNA and copper concentrations, and the primacy of the latter, are validly derived from the data, even in the absence of our ability to identify and measure levels of copper in the intracellular pool controlling metallothionein production.

The present results should be considered together with studies of copper utilization in these mutants. There is striking reduction of biliary excretion of copper $(34,35)$, and impaired utilization of copper in the formation of an extracellular cuproenzyme, lysyl oxidase (36). In contrast, excess cystolic copper is apparently available for normal binding to a cystolic cuproenzyme, superoxide dismutase I (13). The aggregate findings are consistent with the thesis that the mottled or kinky hair syndrome mutation primarily affects copper translocation across cell compartments and/or delivery to a specific copper transport system. Under this hypothesis, the copper so sequestered in specific cell types results in secondary increases in metallothionein mRNA and metal- 
lothionein protein, by normal mechanisms of metallothionein induction and synthesis.

\section{Acknowledgments}

We are most grateful to Dr. M. M. Thaler for important discussions and valuable support of these efforts, and to Dr. D. Cox for his timely contributions and suggestions. We thank Ms. Mary Yagle and Ms. Heidi Holtgreve for excellent technical assistance, and Ms. Phyllis Perry and Ms. Cotys Winston for their tireless and intelligent editorial assistance in the preparation of this manuscript.

This work was supported by U. S. Public Health Service-National Institutes of Health grants GM 28838, HD 09172, and ES 03222, and grant R-811284 from the Environmental Protection Agency.

\section{References}

1. Danks, D. M., P. Campbell, B. Stevens, V. Mayne, and E. Cartwright. 1972. Menkes kinky hair syndrome: an inherited defect in copper absorption with widespread effects. Pediatrics. 50:188-201.

2. Danks, D. M. 1975. Steely hair, mottled mice and copper metabolism. N. Engl. J. Med. 293:1147-1149.

3. Hunt, D. M. 1974. Primary defect in copper transport underlies mottled mutants in the mouse. Nature (Lond.). 249:852-854.

4. Camakaris, J., J. Mann, and D. Danks. 1979. Copper metabolism in mottled mouse mutants. Biochem. J. 180:597-604.

5. Mann, J. R., J. Camakaris, and D. Danks. 1979. Copper metabolism in mottled mouse mutants: distribution of ${ }^{64} \mathrm{Cu}$ in brindled $\left(\mathrm{Mo}^{\mathrm{b}}\right)$ mice. Biochem. J. 180:613-619.

6. Starcher, B., J. A. Madaras, D. Fisk, E. F. Perry, and C. H. Hill. 1978. Abnormal cellular copper metabolism in the blotchy mouse. $J$. Nutr. 108:1229-1233.

7. Packman, S., C. O'Toole, D. Price, and M. Thaler. 1983. Cadmium, zinc and copper metabolism in the mottled mouse, and animal model for Menkes kinky hair syndrome. J. Inorg. Biochem. 19:203-211.

8. Packman, S., and C. O'Toole. 1984. Trace metal metabolism in cultured skin fibroblasts of the mottled mouse: response to metallothionein inducers. Pediatr. Res. 18:1282-1286.

9. Ohno, S. 1974. Conservation of ancient linkage groups in evolution and some insight into the genetic regulatory mechanism of $\mathrm{X}$-inactivation. Cold Spring Harbor Symp. Quant. Biol. 38:155-164.

10. Cox, D., and R. Palmiter. 1983. The metallothionein-1 gene maps to mouse chromosome 8: implications for human Menkes disease. Hum. Genet. 64:61-64.

11. Schmidt, C. J., D. H. Hamer, and O. W. McBride. 1984. Chromosomal location of human metallothionein genes: implications for Menkes disease. Science (Wash. DC). 224:1104-1106.

12. Karin, M., R. L. Eddy, W. M. Henry, L. L. Haley, M. G. Byers, and T. B. Shows. 1984. Human metallothionein genes are clustered on chromosome 16. Proc. Natl. Acad. Sci. USA. 81:5494-5498.

13. Packman, S., P. Chin, and C. O'Toole. 1984. Copper utilization in cultured skin fibroblasts of the mottled mouse: an animal model for Menkes kinky hair syndrome. J. Inherited Metab. Dis. 7:168-170.

14. Leone, A., G. N. Pavlakis, and D. H. Hamer. 1985. Menkes disease: abnormal metallothionein gene regulation in response to copper. Cell. 40:301-309.

15. Danks, D. M. 1983. Hereditary disorders of copper metabolism in Wilson's disease and Menkes disease. In The Metabolic Basis of Inherited Disease. J. Stanbury, J. Wyngaarden, D. Frederickson, J. Goldstein, and M. Brown, editors. McGraw-Hill Book Co., New York. 12511268.

16. Markwell, M., S. Haas, L. Bieber, and N. Tolbert. 1978. A mod- ification of the Lowry procedure to simplify protein determination in membrane and lipoprotein samples. Anal. Biochem. 87:206-210.

17. Durnam, D. M., and R. D. Palmiter. 1983. A practical approach for quantitating specific mRNA's by solution hybridization. Anal. Biochem. 131:385-393.

18. Durnam, D. M., F. Perrin, F. Gannon, and R. D. Palmiter. 1980. Isolation and characterization of the mouse metallothionein-I gene. Proc. Natl. Acad. Sci. USA. 77:6511-6515.

19. Durnam, D. M., and R. D. Palmiter. 1981. Transcriptional regulation of the mouse metallothionein-I gene by heavy metals. J. Biol. Chem. 256:5712-5716.

20. Karin, M., and R. Richards. 1982. Human metallothionein genes: molecular cloning and sequence analysis of the mRNA. Nucleic Acids Res. 10:3165-3173.

21. Karin, M., and R. Richards. 1982. Human metallothionein genes: primary structure of the metallothionein-11 gene and a related processed gene. Nature (Lond.). 299:797-802.

22. Richards, R. I., A. Heguy, and M. Karin. 1984. Structural and functional analysis of the human metallothionein-1A gene: differential induction by metal ions and glucocorticoids. Cell. 37:263-272.

23. Snedecor, G. W., and W. G. Cochran. 1980. Statistical Methods. Iowa State University Press, Ames, IA. 144-146.

24. Dixon, W. J., and F. J. Massey, Jr. 1969. Introduction to Statistical Analysis. McGraw-Hill Book Co., New York. 193-221.

25. Holtzman, N. A. 1976. Menkes kinky hair syndrome: a genetic disease involving copper. Fed. Proc. 35:2276-2280.

26. Danks, D., E. Cartwright, B. Stevens, and R. Townley. 1973. Menkes kinky hair disease: further definition of the defect in copper transport. Science (Wash. DC). 179:1140-1142.

27. Cousins, R. J. 1983. Metallothionein: aspects related to copper copper and zinc metabolism. J. Inherited Metab. Dis. 6(Suppl. 1):1521.

28. Bonewitz, R. F., and R. R. Howell. 1981. Synthesis of a metallothionein-like protein in cultured human skin fibroblasts: relation to abnormal copper distribution in Menkes disease. J. Cell. Physiol. 106: 339-348.

29. Prins, H. W., and C. J. A. Van den Hamer. 1979. Primary biochemical defect in copper metabolism in mice with a recessive $X$-linked mutation analogous to Menkes disease in man. J. Inorg. Biochem. 10: 19-27.

30. Labadie, G. U., K. Hirschhorn, S. Katz, and N. G. Beratis. 1981. Increased copper metallothionein in Menkes cultured skin fibroblasts. Pediatr. Res. 15:257-261.

31. Riordan, J. R., and L. Jolicoeur-Paquet. 1982. Metallothionein accumulation may account for intracellular copper retention in Menkes disease. J. Biol. Chem. 257:4639-4645.

32. Labadie, G. U., N. G. Beratis, P. M. Price, and K. Hirschhorn. 1981. Studies of the copper-binding proteins in Menkes and normal cultured skin fibroblast lysates. J. Cell. Physiol. 106:173-178.

33. Chan, W. Y., A. D. Garnica, and O. M. Rennert. 1979. Inducibility of metallothionein biosynthesis in cultured normal and Menkes kinky hair disease fibroblasts: effects of copper and cadmium. Pediatr. Res. 13: 197-203.

34. Castillo, R., M. Thaler, V. Ling, C. O'Toole, and S. Packman. 1982. Defective biliary copper excretion in the blotchy mouse. Clin. Res. 30:116A.

35. Mann, J., J. Camakaris, and D. Danks. 1980. Copper metabolism in mottled mouse mutants: distribution of ${ }^{64} \mathrm{Cu}$ in brindled $\left(\mathrm{Mo}^{\mathrm{b}}\right)$ mice. Biochem. J. 180:613-619.

36. Royce, P., J. Camakaris, and D. Danks. 1980. Reduced lysyl oxidase activity in skin fibroblasts from patients with Menkes syndrome. Biochem. J. 192:579-586. 